\title{
Relationship between Formula Milk and the Incidence Obesity in Children Under Five: Meta-Analysis
}

\author{
Elma Yopiana'), Yulia Lanti Retno Dewi²), Bhisma Murti') \\ 1)Masters Program in Public Health, Universitas Sebelas Maret \\ 2)Faculty of Medicine, Universitas Sebelas Maret
}

Background: Obesity is a nutritional disorder that most often occurs in children. Obesity is associated with worse health outcomes in children, including asthma and sleep apnea. This study aimed to examine the relationship between formula feeding and obesity in children under five.

Subjects and Method: This was a metaanalysis study conducted by systematically reviewing articles from PubMed, Science Direct, Springer Link, and Google Scholar. The articles used in this research are articles that have been published from 2008-2016. The search for articles was carried out by considering the eligibility criteria using the PICO model, P: toddlers, I: formula feeding, C: breastfeeding, O: obesity. The key words for finding articles were as follows: "OR" Formula milk "OR" Infant Formula") AND" Breast Feeding "AND (Obesity OR" Body Mass Index"). The inclusion criteria used were full paper, used English, cohort and cross-sectional observational study design and the results reported were adjusted odds ratio. Articles were collected using PRISMA diagrams, and analyzed using the Review Manager 5.3 application.

Results: A total of 9 articles were conducted meta-analysis in this study with a sample size of 26,119 . The results of the meta-analysis of the cohort study showed that formula feeding increased the incidence of obesity in children under five $(\mathrm{aOR}=1.10 ; 95 \% \mathrm{CI}=0.78$ to 1.56 ; $\mathrm{p}=0.570$ ). The results of the meta-analysis of cross-sectional studies showed that formula feeding increased the incidence of obesity in children under five $(\mathrm{aOR}=1.25 ; 95 \% \mathrm{CI}=0.59$ to $2.63 ; \mathrm{p}=0.560$ ).

Conclusion: Formula feeding increases the incidence of obesity in children under five.

Keywords: Obesity, formula, toddlers, metaanalysis

\section{Correspondence:}

Elma Yopiana. Masters Program in Public Health. Universitas Sebelas Maret, Jl. Ir. Sutami 36A, Surakarta 57126, Jawa Tengah, Indonesia. Email: elmayopiana@gmail.com.

\section{Cite this as:}

Yopiana E, Dewi YLR, Murti B (2020). Relationship between Formula Milk and the Incidence Obesity in Children Under Five: Meta-Analysis. Indones J Med. 05(04): 299-307. https://doi.org/10.26911/theijmed.2020.05.04.05.

cc (i) (-) Indonesian Journal of Medicine is licensed under a Creative Commons

EY NC SA Attribution-NonCommercial-ShareAlike 4.0 International License.

\section{BACKGROUND}

Childhood obesity is a major public health problem (Mallan et al., 2018). Obesity is the most common nutritional disorder in children. Preventing obesity in children should be a useful strategy in preventing future heart disease because weight loss interventions in obese children are difficult and rarely successful (Campoy et al. al., 2018).

In 2016, an estimated 38.3 million children were overweight or obese. The problem of obesity has grown to epidemic proportions, with more than 4 million people dying each year as a result of being overweight or obese in 2017 according to the global disease burden (WHO, 2020). 
Obesity is associated with worse health outcomes in children, including asthma and sleep apnea and adults who are obese have an increased risk of cardiovascular disease (CVD), type 2 diabetes and some cancers. Therefore, reducing the risk of obesity is a priority for public health (Lanigan, 2020).

The World Health Organization (WHO) and the United Nations International Children's Fund (UNICEF) recommend early initiation of breastfeeding within 1 hour of birth, exclusive breastfeeding during the first 6 months of life, and introduction of nutritionally adequate and safe complementary foods at 6 months of age together with continued breastfeeding until 2 years of age or more. However, many babies and children do not receive optimal nourishment.

WHO is actively promoting breastfeeding as the best source of food for infants and young children, and is working to increase the rate of exclusive breastfeeding during the first 6 months to at least 50\% by 2025 (WHO, 2020).

Formula milk is prepared as a nutritional substitute for breast milk, but due to differences in biology and constituents, it can cause obesity and growth disorders in infants (Synaii, 2019). The difference between formula milk and breast milk is that formula milk is justfood. In contrast, breast milk is a complex, living nutrient liquid containing antibodies, enzymes and hormones, all of which have health benefits (Savino et al., 2009). Children who are fed formula milk earlier after delivery are more likely to show rapid growth than children who are breastfed. Children who are fed formula milk are more often obese and come from families with lower social status than children who are breastfed alone (Toftlund et al., 2018).
SUBJECTS AND METHOD

\section{Study Design}

This was a meta-analysis research. Data search was carried out systematically and comprehensively through PubMed, Science Direct, Springer Link, and Google Scholar databases. Search keywords used were: "Children Under Five" AND ("non Breast Feeding" OR "Formula milk" OR "Infant Formula") AND "Breast Feeding" AND (Obesity OR "Body Mass Index").

\section{Inclusion Criteria}

The author developed the inclusion criteria, namely full text English articles with a cohort and cross-sectional study design. The research subjects were children aged 1 month - 5 years. The therapy given is formula milk. The analysis used was multivariate with adjusted odds ratio and the outcome was obesity.

\section{Exclusion Criteria}

The exclusion criterion in this study was a non cross-sectional study, articles that were not full text and published before 2005 . Articles published in languages other than English and not a multivariate analysis study.

\section{Operational Definition of Variables}

The article search was carried out by considering the eligibility criteria defined using the PICO model. The population in the study were toddlers with intervention in the form of formula milk, comparison of breastfeeding and obesity outcomes.

Obesity is a body condition that is assessed based on indicators of body weight according to body length, which is more than 3 standard deviations above the median of the Child Growth Standard. The instrument used was a height measuring instrument, a weight measuring instrument with a continuous measuring scale.

Formula feeding is defined as a condition in which a child is given formula milk, either partially or totally at the age of less 
than 6 months. The instrument was a questionnaire with a dichotomy measuring scale.

\section{Data Analysis}

Articles were collected using PRISMA diagrams, and analyzed using the Review Manager 5.3 application by calculating the effect size and heterogeneity to determine which research models were combined to form the final meta-analysis result.

\section{RESULTS}

The article review process can be seen in the PRISMA flow diagram Figure 1. This meta-analysis analyzes 9 primary studies conducted in the Netherlands, Sweden, China, Brazil, Australia and Indonesia.

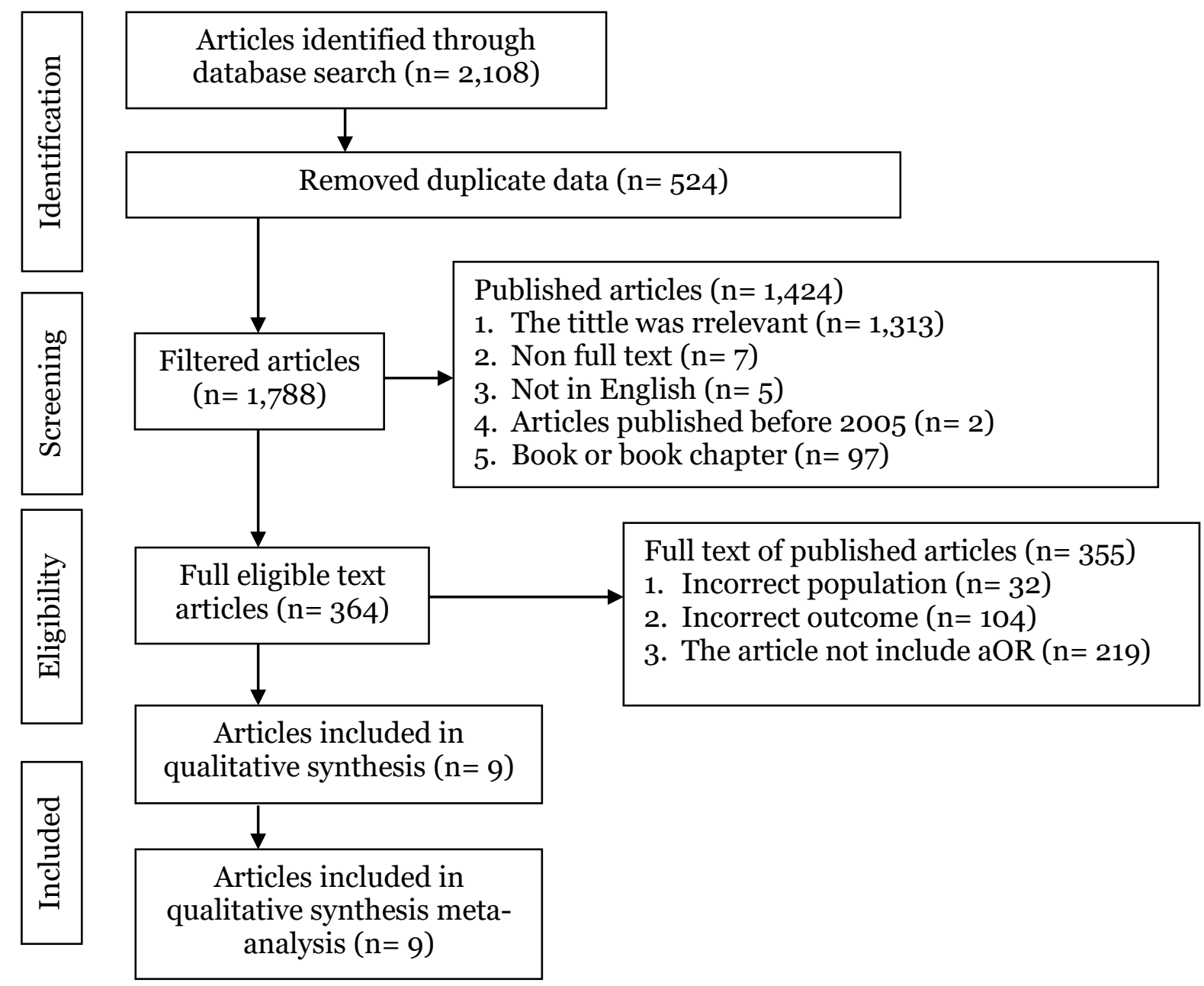

Figure 1. PRISMA flow diagram

The study quality assessment was carried out quantitatively. This study uses the Critical Appraisal Skills Program (CASP) for Cohort Study (Center for Evidence Based Management, 2014; NHS,
2004; 2006). Assessment of the quality of the study research was also carried out using critical appraisal tools from the center for evidence-based management in a cross-sectional design. 
Yopiana et al./ Formula Milk and the Incidence Obesity in Children Under Five

Table 1. Assessment of the quality of the cohort study

\begin{tabular}{|c|c|c|c|c|c|c|c|c|c|c|c|c|c|}
\hline \multirow{2}{*}{ Primary Study } & \multicolumn{13}{|c|}{ Criteria } \\
\hline & $\mathbf{1}$ & 2 & 3 & 4 & 5 & 6 & 7 & 8 & 9 & $\mathbf{1 0}$ & $\mathbf{1 1}$ & 12 & Total \\
\hline Contarato et al. (2016) & 1 & 1 & 1 & 1 & 1 & 1 & 1 & $\mathrm{O}$ & 1 & 1 & 1 & 1 & 11 \\
\hline Huang et al. (2014). & 1 & 1 & 1 & 1 & 1 & 1 & 1 & 1 & 1 & 1 & 1 & 1 & 12 \\
\hline Huss et al. (2008). & 1 & 1 & $\mathrm{O}$ & $\mathrm{O}$ & 1 & 1 & 1 & 1 & 1 & 1 & 1 & 1 & 10 \\
\hline Kuperset al. (2015). & 1 & 1 & 1 & 1 & 1 & 1 & 1 & 1 & 1 & 1 & 1 & 1 & 12 \\
\hline Pluymenet al. (2018) & 1 & 1 & 1 & 1 & 1 & 0 & 0 & 1 & 1 & 1 & 1 & 1 & 10 \\
\hline Zhang et al. (2013). & 1 & 1 & 1 & 1 & 1 & 1 & o & $\mathrm{O}$ & 1 & 1 & 1 & 1 & 10 \\
\hline \multicolumn{14}{|c|}{ Table 2. Assessment of the quality of the cross-sectional design study } \\
\hline \multirow{2}{*}{ Primary Study } & \multicolumn{13}{|c|}{ Criteria } \\
\hline & $\mathbf{1}$ & 2 & 3 & 4 & 5 & 6 & 7 & 8 & 9 & 10 & $\mathbf{1 1}$ & 12 & Total \\
\hline Gopinath et al. (2012) & 1 & 1 & 1 & 0 & 1 & 1 & 1 & 1 & 1 & 1 & 1 & 1 & 11 \\
\hline Mangrio et al. (2012) & 1 & 1 & 1 & $\mathrm{O}$ & o & o & 1 & 1 & 1 & 1 & 1 & 1 & 9 \\
\hline Rachmi et al. (2016) & 1 & 1 & 1 & $\mathrm{O}$ & 1 & 1 & 1 & 1 & 1 & 1 & $\mathrm{O}$ & 1 & 10 \\
\hline
\end{tabular}

\section{a. Formula feeding against obesity}

Research related to the relationship of formula feeding with the incidence of obesity in children under five consisted of 9 articles from 4 continents, namely the
Asian Continent (3 articles), the Americas (1 article), the European Continent (4 articles) and the Australian Continent (1 article). Nine articles prove the link of formula feeding to obesity.

\section{b. Forest plot}

\begin{tabular}{|c|c|c|c|c|c|c|c|c|}
\hline Study or Subgroup & log[Odds Ratio] & SE & Weight & $\begin{array}{l}\text { Odds Ratio } \\
\text { IV, Random, } 95 \% \mathrm{Cl}\end{array}$ & & $\begin{array}{r}\text { Odds } \\
\text { IV, Rand }\end{array}$ & $\begin{array}{l}\text { s Ratio } \\
\text { om, } 95 \% \mathrm{Cl}\end{array}$ & \\
\hline \multicolumn{9}{|l|}{ 1.1.1 Cohort } \\
\hline Contarato 2016 & 0.5306 & 0.2707 & $12.3 \%$ & $1.70[1.00,2.89]$ & & & & \\
\hline Huang 2014 & -0.1393 & 0.2248 & $14.0 \%$ & $0.87[0.56,1.35]$ & & & & \\
\hline Huss 2008 & 0.1989 & 0.209 & $14.6 \%$ & $1.22[0.81,1.84]$ & & & & \\
\hline Kupers 2015 & -1.7661 & 0.7674 & $3.3 \%$ & $0.17[0.04,0.77]$ & & & & \\
\hline Pluymen 2018 & 0.4121 & 0.1302 & $17.5 \%$ & $1.51[1.17,1.95]$ & & & $\rightarrow$ & \\
\hline $\begin{array}{l}\text { Zhang } 2013 \\
\text { Subtotal }(95 \% \mathrm{Cl})\end{array}$ & -0.2485 & 0.3805 & $\begin{array}{r}8.9 \% \\
70.5 \%\end{array}$ & $\begin{array}{l}0.78[0.37,1.64] \\
1.10[0.78,1.56]\end{array}$ & & & & \\
\hline \multicolumn{9}{|c|}{$\begin{array}{l}\text { Heterogeneity: } \text { Tau }^{2}=0.11 ; \mathrm{Chi}^{2}=14.26, \mathrm{df}=5(P=0.01) ;\left.\right|^{2}=65 \% \\
\text { Test for overall effect: } Z=0.56(P=0.57)\end{array}$} \\
\hline \multicolumn{9}{|l|}{ 1.1.2 Cross-Sectional } \\
\hline Gopinath 2012 & -0.5276 & 0.3451 & $9.9 \%$ & $0.59[0.30,1.16]$ & & & & \\
\hline Mangrio 2012 & 0.47 & 0.3109 & $10.9 \%$ & $1.60[0.87,2.94]$ & & & & \\
\hline $\begin{array}{l}\text { Rachmi } 2016 \\
\text { Subtotal }(95 \% \mathrm{Cl})\end{array}$ & 0.7467 & 0.3861 & $\begin{array}{r}8.8 \% \\
29.5 \%\end{array}$ & $\begin{array}{l}2.11[0.99,4.50] \\
1.25[0.59,2.63]\end{array}$ & & & & \\
\hline \multicolumn{9}{|c|}{$\begin{array}{l}\text { Heterogeneity: } \mathrm{Tau}^{2}=0.31 ; \mathrm{Chi}^{2}=7.20, \mathrm{df}=2(\mathrm{P}=0.03) ; \mathrm{I}^{2}=72 \% \\
\text { Test for overall effect: } Z=0.59(\mathrm{P}=0.56)\end{array}$} \\
\hline Total $(95 \% \mathrm{Cl})$ & & & $100.0 \%$ & $1.14[0.85,1.54]$ & & & & \\
\hline \multicolumn{5}{|c|}{$\begin{array}{l}\text { Heterogeneity: } \mathrm{Tau}^{2}=0.12 ; \mathrm{Chi}^{2}=21.46, \\
\text { Test for overall effect: } \mathrm{Z}=0.86(\mathrm{P}=0.39) \\
\text { Test for subaroun differences: } \mathrm{Ch}^{2}=0.09\end{array}$} & 0.01 & $\begin{array}{l}0.1 \\
\text { Breastfeeding }\end{array}$ & Formula Milk & 100 \\
\hline
\end{tabular}

Figure 2. Forest plot of feeding relationship formula with the incidence of obesity in toddlers 
Yopiana et al./ Formula Milk and the Incidence Obesity in Children Under Five

Table 3. Descriptions of primary studies included in the meta-analysis

\begin{tabular}{|c|c|c|c|c|c|c|c|}
\hline $\begin{array}{l}\text { Author } \\
\text { (Year) }\end{array}$ & Country & $\begin{array}{l}\text { Study } \\
\text { Design }\end{array}$ & Sample & $\begin{array}{c}\mathbf{P} \\
\text { (Population) }\end{array}$ & $\begin{array}{c}\text { I } \\
\text { (Intervention) }\end{array}$ & $\begin{array}{c}\mathrm{C} \\
\text { (Comparison) }\end{array}$ & $\begin{array}{c}\text { O } \\
\text { (Outcome) }\end{array}$ \\
\hline $\begin{array}{l}\text { Contarato et } \\
\text { al. (2016). }\end{array}$ & Brazil & Cohort & 435 & $\begin{array}{l}\text { Children 12-24 } \\
\text { months of age. }\end{array}$ & Formula feeding. & $\begin{array}{l}\text { Exclusive breastfeed- } \\
\text { ing, juice, fruit or tea. }\end{array}$ & Overweight, obese. \\
\hline $\begin{array}{l}\text { Gopinath et } \\
\text { al. (2012). }\end{array}$ & Australia & $\begin{array}{l}\text { Cross- } \\
\text { sectional }\end{array}$ & 731 & $\begin{array}{l}\text { Children aged } \\
3-4 \text { years. }\end{array}$ & $\begin{array}{l}\text { Children who are not exclu- } \\
\text { sively breastfed, including } \\
\text { formula feeding. }\end{array}$ & $\begin{array}{l}\text { Exclusive } \\
\text { breastfeeding and } \\
\text { duration. }\end{array}$ & $\begin{array}{l}\text { Difference in BMI } \\
\text { and obesity. }\end{array}$ \\
\hline $\begin{array}{l}\text { Huang et al. } \\
\text { (2014) }\end{array}$ & Cina & Cohort & 1,093 & $\begin{array}{l}\text { Infants } 3-12 \\
\text { months of age. }\end{array}$ & Formula feeding & Breastfeeding & $\begin{array}{l}\text { Growth and } \\
\text { obesity. }\end{array}$ \\
\hline $\begin{array}{l}\text { Huss et al. } \\
\text { (2008) }\end{array}$ & Swedia & Cohort & 7,356 & $\begin{array}{l}\text { Children aged } \\
5 \text { years. }\end{array}$ & $\begin{array}{l}\text { Children who are not exclu- } \\
\text { sively breastfed, including } \\
\text { formula feeding. }\end{array}$ & $\begin{array}{l}\text { Exclusive } \\
\text { breastfeeding. }\end{array}$ & Obesity. \\
\hline $\begin{array}{l}\text { Kupers et al. } \\
\text { (2015). }\end{array}$ & $\begin{array}{c}\text { Belanda } \\
.\end{array}$ & Cohort & 2,475 & $\begin{array}{l}\text { Children aged } \\
1-24 \text { months. }\end{array}$ & Formula feeding. & Breastfeeding. & $\begin{array}{l}\text { Growth patterns, } \\
\text { obesity. }\end{array}$ \\
\hline $\begin{array}{l}\text { Mangrio et } \\
\text { al. (2012). }\end{array}$ & Swedia & $\begin{array}{l}\text { Cross- } \\
\text { sectional }\end{array}$ & 9,009 & $\begin{array}{l}4 \text { year old } \\
\text { child. }\end{array}$ & $\begin{array}{l}\text { Children who are not exclu- } \\
\text { sively breastfed, including } \\
\text { formula feeding. }\end{array}$ & $\begin{array}{l}\text { Exclusive } \\
\text { breastfeeding. }\end{array}$ & Obesity. \\
\hline $\begin{array}{l}\text { Pluymen et } \\
\text { al. (2018) }\end{array}$ & Belanda & Cohort & 2,611 & $\begin{array}{l}\text { Infants } 3-12 \\
\text { months of age. }\end{array}$ & $\begin{array}{l}\text { Providing formula milk and } \\
\text { complementary foods from an } \\
\text { early age. }\end{array}$ & Breastfeeding. & Obesity \\
\hline $\begin{array}{l}\text { Rachmi et al. } \\
\text { (2016) }\end{array}$ & Indonesia & $\begin{array}{l}\text { Cross- } \\
\text { sectional }\end{array}$ & 1,311 & $\begin{array}{l}\text { Children aged } \\
2.0-4.9 \text { years. }\end{array}$ & $\begin{array}{l}\text { Complementary feeding before } \\
6 \text { months of age, including } \\
\text { formula feeding. }\end{array}$ & $\begin{array}{l}\text { Exclusive } \\
\text { breastfeeding. }\end{array}$ & $\begin{array}{l}\text { Being overweight } \\
\text { and obese. }\end{array}$ \\
\hline $\begin{array}{l}\text { Zhang et al. } \\
\text { 2013). }\end{array}$ & Cina & Cohort & 1,098 & $\begin{array}{l}2 \text { years old } \\
\text { children }\end{array}$ & $\begin{array}{l}\text { Mixed breastfeeding includes } \\
\text { formula feeding. }\end{array}$ & $\begin{array}{l}\text { Exclusive } \\
\text { breastfeeding. }\end{array}$ & Obesity \\
\hline
\end{tabular}




\section{c. Funnel plot}

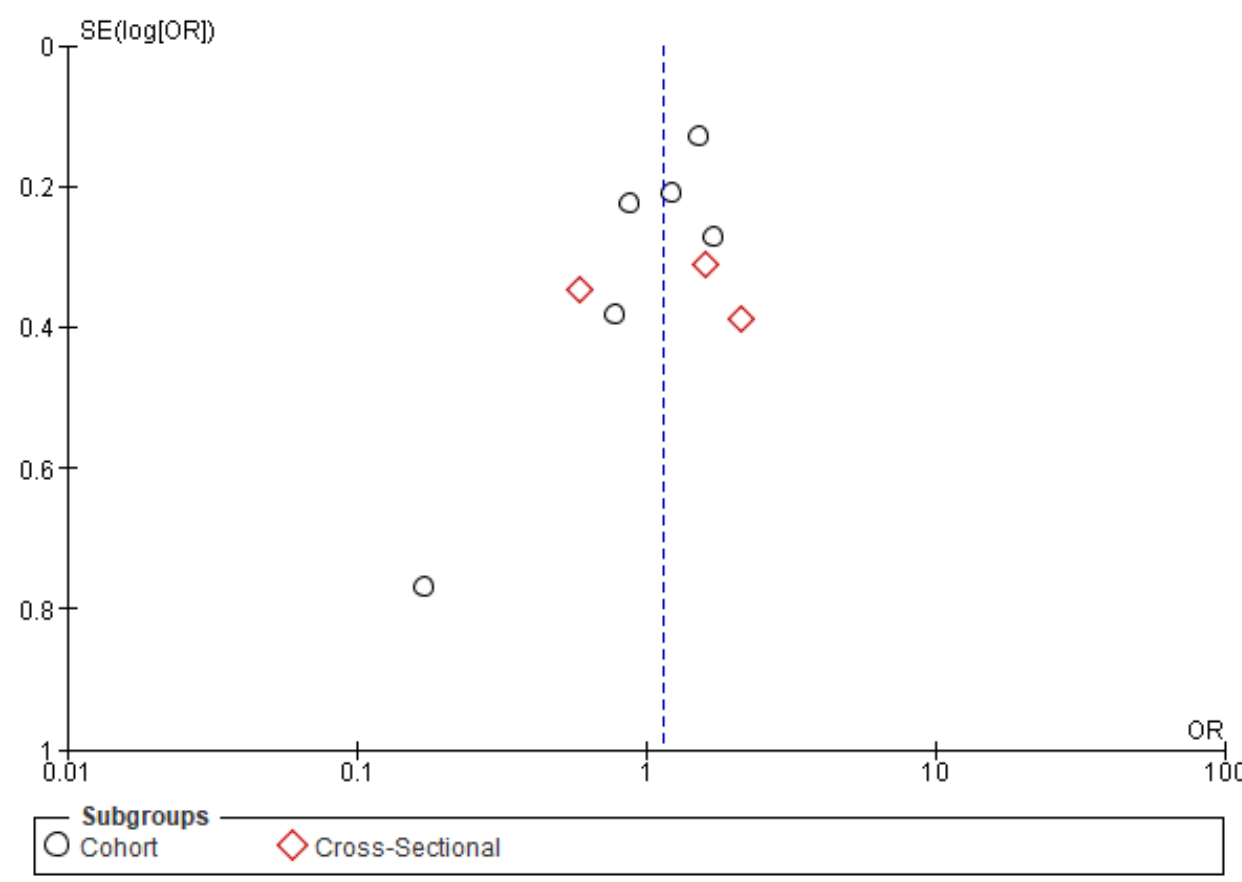

Figure 3. Funnel plot of formula feeding with the incidence of obesity in toddlers

The results from the forest plot (Figure 2) show that formula feeding increases the incidence of obesity in children under five. The meta-analysis results of the cohort study showed that formula feeding increased the incidence of obesity in children under five by 1.10 times compared to breastfeeding $(\mathrm{p}=0.570)$. The heterogeneity of the research data shows $\mathrm{I}^{2}=65 \%$ so that the distribution of the data is declared heterogeneous (random effect model).

The results of the meta-analysis of cross-sectional studies showed that formula feeding increased the incidence of obesity in children under five by 1.25 times compared to breastfeeding $(\mathrm{p}=0.560)$. The heterogeneity of the research data shows $\mathrm{I}^{2}=72 \%$ so that the distribution of the data is stated to be heterogeneous (random effect model).

The funnel plot (figure 3) shows that the plots on the right and left are not sym- metrical with each other and do not form an inverted funnel, with 5 plots on the right and 4 plots on the left. The plot on the left of the graph appears to have a standard error between 0.2 and 0.8 and the plot on the right has a standard error between 0 and o.6. This indicates that there is a publication bias in the study.

\section{DISCUSSION}

This systematic study and meta-analysis research raises the theme of formula feeding on the incidence of obesity in children under five. The independent variable analyzed was formula feeding.

This meta-analysis study was conducted using a study that controls the confounding factor which can be seen from the study inclusion requirements, namely multivariate analysis and the statistical result reported is the adjusted odds ratio (aOR). Estimates of the combined relationship between formula feeding and the inci- 
dence of obesity in children under five were processed using the RevMan 5.3 application. The results of the systematic study and meta-analysis are presented in the form of a forest plot and a funnel plot.

\section{Formula feeding against obesity}

The results of the forest plot indicate that formula feeding increases the incidence of obesity in children under five. The results of the meta-analysis of the cohort study showed that formula feeding increased the incidence of obesity in infants by 1.10 times compared to breastfeeding and the metaanalysis of cross-sectional studies showed that formula feeding increased the incidence of obesity in children under five by 1.25 times compared to breastfeeding.

A study by Hopkins et al. (2015) which aims to determine the effect of feeding the type of milk during infants on child recovery shows that formula feeding is associated with faster weight gain and height than breastfeeding ( $\mathrm{p}=0.001)$. This study is in line with the research of Synaii et al. (2019) which aims to compare the growth patterns of formula-fed and breastfed babies in Iran. The results showed that BMI was significantly higher in the infant formula group ( $\mathrm{p}=0.020)$.

The meta-analysis research conducted by Owen et al. (2005) stated that formula feeding was associated with a slightly higher BMI than those who received breast milk $(\mathrm{p}=0.002)$. Other research conducted by Beckett and Meldrum (2018) shows that there is evidence that unhealthy feeding practices, namely the introduction of solid food too early and formula feeding are predictive factors for obesity in early childhood.

Formula-fed babies grow differently from breastfed in that they are heavier after four to six months of age. This difference should be anticipated to limit formula feeding or dietary intake (Dietitians of
Canada and Canadian Pediatric Society, 2010). Formula milk has a higher protein content than breast milk. The results showed a positive relationship between initial protein intake and obesity, there was a higher BMI in the high protein intake compared to the low protein group (Davanzo et al., 2016).

Exclusive breastfeeding is recommended until the baby is around six months old. Therefore, giving formula milk before 6 months of age is not recommended (Wilson, 2008). In the recommended preage formula feeding, several things should be considered, namely when there is a medical contraindication to breastfeeding, the milk production is really low and has fully informed the mother that bottle feeding is a better alternative in certain circumstances.

Effective intervention programs can facilitate improvements in feeding practices to further support healthy care among infants and toddlers (Taha et al., 2020). Factors that help mothers not to provide other than breast milk until the age of six months is a trusting relationship with health workers, consistent advice and recommendations so that the mother accepts it easily and enthusiastically (Walsh et al., 2015).

Policies to overcome the burden of malnutrition and the threat of obesity and obesity rests on three main pillars. The first is scaling up specific nutrition or direct interventions, which include infant and young child feeding, changes in communication behavior to improve nutritional status, micronutrient supplementation, and treatment of severe acute malnutrition. The second objective is to cultivate or be sensitive to indirect nutritional interventions. These include food insecurity alleviation, promotion of agricultural nutrition-friendly, aquaculture, introducing nutrients into 
social safety net programs, sanitizing water, and promoting preventive measures against overweight and obesity. The third objective is to promote multi-sectoral efforts and coordination of all actions at the national level (Ahmed, 2017).

The limitation in this study is that there is a publication bias that is shown in the funnel plot, language bias occurs because in this study the selected articles are only those published in English so that they ignore articles that use other languages, as well as search bias because in this study the researchers only used 4 databases (PubMed, Science Direct, Springer Link, and Google Scholar) thus ignoring other search sources.

\section{AUTHOR CONTRIBUTION}

Elma is the principal researcher who selects topics, searches and collects research data. Yulia Lanti and Bhisma Murti played a role in analyzing data and reviewing research documents.

\section{CONFLICT OF INTEREST}

There is no conflict of interest in this study.

\section{FUNDING AND SPONSORSHIP}

This study is self-funded.

\section{ACKNOWLEDGEMENT}

We are very grateful to the database: PubMed, Science Direct, Springer Link and Google Scholar.

\section{REFERENCES}

Ahmed T (2017). Burden of undernutrition and overweight/obesity - Policy and programme in Bangladesh. Dhaka: Nutrition and Clinical Services Division International Centre for Diarrhoeal Disease Research Bangladesh.

Anonymous (2010). Promoting optimal monitoring using the New WHO
Growth Charts. Canada: Dietitians of

Canada and Canadian Paediatric Society.

Beckett DM, Meldrum AM (2018). Health and wellbeing of under-five year olds in the South Island 2017. New Zealand: New Zealand Child and Youth Epidemiology Service.

Campoy C, Campos D, Cerdó T, Diéguez E, Garciá-Santos JA (2018). Complementary feeding in developed countries: the 3 ws (when, what, and why?). Ann Nutr Metab, 73 (1): 2736. https://doi.org/10.1159/000490086.

Davanzo R, Bua J, Travan L (2016). Human Milk and Formulas for Neonatal Nutrition. Neonatology: 1-30. https://doi.org/10.1007/978-3-319-18159-2_185-2.

Hopkins D, Steer CD, Northstone K, Emmett PM (2015). Effects on childhood body habitus of feeding large volumes of cow or formula milk compared with breastfeeding in the latter part of infancy. Am J Clin Nutr, 102(5): 1096-1103. https://dx.doi.org/10.3945\%2Fajen.114.100529.

Lanigan J (2020). Interventions to improve nutrition in urban areas prevention of overweight and obesity in early life proceedings of the nutrition society proceedings of the nutrition society. Proc Nutr Soc, 77 (5): 247-256.

Mallan KM, Daniels LA, Byrne R (2018). Comparing barriers to breastfeeding success in the first month for nonoverweight and overweight women. BMC Pregnancy Childbirth. 18, 461 (2018). https://doi.org/10.1186/s12884-018-2094-5.

Owen CG, Martin RM, Whincup PH, Daveysmith G, Gillman MW, Cook DG (2005). The effect of breastfeeding on mean body mass index throughout 
life: a quantitative review of published and unpublished observational evidence. Am J Clin Nutr, 82(6): 12981307. https://doi.org/10.1093/ajcn/82.6.1298.

Savino F, Fissore MF, Liguori SA, Oggero R (2009). Can hormones contained in mothers milk account for the beneficial effect of breast-feeding on obesity in children?. Clin Endocrinol (Oxf), 71: 757-765. https://doi.org/10.1111/j.1365-2265.2009.03585.x.

Synaii S (2019). Growth indices of exclusively breastfed until 6 months age and formula - fed infants in Southwest of Iran. Int J Prev Med, 10 (207): 1-5. https://dx.doi.org/10.4103\%2Fijpvm. IJPVM_36_18.

Taha Z, Garemo M, Nanda J (2020). Complementary feeding practices among infants and young children in $\mathrm{Abu}$ Dhabi, United Arab Emirates. BMC Public Health, 20(1). https://doi.org/10.1186/s12889-020-09393-y.
Toftlund LH, Halken S, Agertoft L, Zachariassen $G$ (2018). Early nutrition and signs of metabolic syndrome at $6 \mathrm{y}$ of age in children born very preterm. Am J Clin Nutr, 107 (1): 717-724. https://doi.org/10.1093/ajcn/nqyo15.

Walsh A, Kearney L, Dennis N (2015). Factors influencing first-time mothers' introduction of complementary foods: A qualitative exploration. BMC Public Health, 15(1). https://dx.doi.org/10.1186\%2Fs12889-015-2250-z.

Wilson (2008). Food and nutrition guidelines for healthy adults: A background paper. https://www.nzihf.co.nz/media-resources-1/articles/personal\%2otraining-nutrition-guidelinesadults.

WHO (2020). Childgrowth. Global Health Observatory (GHO) data: World Health Organization. 